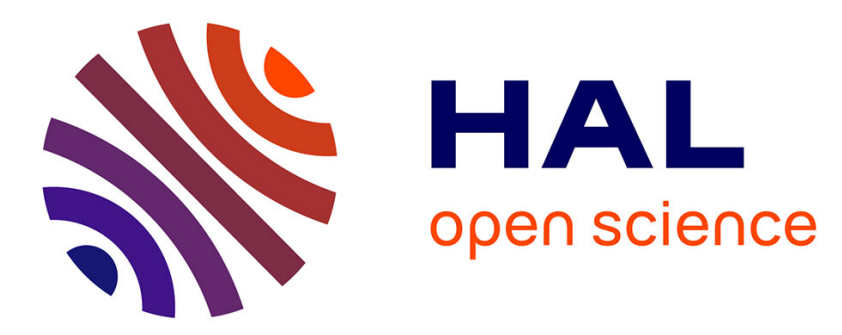

\title{
Progressive Evolution of the Changjiang (Yangtze River) Sediment Weathering Intensity Since the Three Gorges Dam Operation
}

\author{
Chengfan Yang, Shouye Yang, Jiaze Song, Nathalie Vigier
}

\section{- To cite this version:}

Chengfan Yang, Shouye Yang, Jiaze Song, Nathalie Vigier. Progressive Evolution of the Changjiang (Yangtze River) Sediment Weathering Intensity Since the Three Gorges Dam Operation. Journal of Geophysical Research: Earth Surface, 2019, 124, pp.2402 - 2416. 10.1029/2019jf005078 . hal03130843

\section{HAL Id: hal-03130843 \\ https://hal.science/hal-03130843}

Submitted on 4 Feb 2021

HAL is a multi-disciplinary open access archive for the deposit and dissemination of scientific research documents, whether they are published or not. The documents may come from teaching and research institutions in France or abroad, or from public or private research centers.
L'archive ouverte pluridisciplinaire HAL, est destinée au dépôt et à la diffusion de documents scientifiques de niveau recherche, publiés ou non, émanant des établissements d'enseignement et de recherche français ou étrangers, des laboratoires publics ou privés. 


\section{JGR Earth Surface}

\author{
RESEARCH ARTICLE \\ 10.1029/2019JF005078 \\ Key Points: \\ - Sediments collected downstream of \\ the Three Gorges Dam displayed \\ progressive but significant increase \\ in weathering intensity since 2003 \\ - Simple mass balance calculation \\ indicates progressive addition of \\ strongly weathered sediments since \\ the Three Gorges Dam operation \\ - A core collected in the lower \\ mainstream demonstrates that in \\ situ weathered midlower riverbed \\ sediments correspond to the missing \\ source
}

Supporting Information:

- Supporting Information S1

Correspondence to:

C. Yang,

chengfan.yang@obs-vlfr.fr

Citation:

Yang, C., Yang, S., Song, J., \& Vigier, N. (2019). Progressive evolution of the Changjiang (Yangtze River) sediment weathering intensity since the Three Gorges Dam Operation. Journal of Geophysical Research: Earth Surface, 124, 2402-2416. https://doi.org/ 10.1029/2019JF005078

Received 14 MAR 2019 Accepted 9 SEP 2019

Accepted article online 12 SEP 2019

Published online 28 OCT 2019

(c)2019. American Geophysical Union. All Rights Reserved.

\section{Progressive Evolution of the Changjiang (Yangtze River) Sediment Weathering Intensity Since the Three Gorges Dam Operation}

\author{
Chengfan Yang ${ }^{1,2}$ (D), Shouye Yang ${ }^{1}\left(\mathbb{D}\right.$, Jiaze Song ${ }^{1}$, and Nathalie Vigier ${ }^{2}$ \\ ${ }^{1}$ State Key Laboratory of Marine Geology, Tongji University, Shanghai, China, ${ }^{2}$ Oceanography Laboratory of Villefranche \\ (LOV), CNRS, Sorbonne University, Paris, France
}

\begin{abstract}
Chemical composition of river sediments and dissolved load is classically used to infer controls on continental weathering and, therefore, exert an important role on the understanding of the global carbon and biogeochemical cycles. To date, most studied river basins are strongly impacted by dam constructions; however, the effects of dams on sediment chemical compositions are little known. The Three Gorges Dam is one of the largest dams in the world and began impounding water in 2003 in the Changjiang basin. In order to investigate the impact of this dam on downstream sediment chemistry, temporal variation of sediment weathering intensity is reported here based on analyzed and compiled data between 1997 and 2018. Downstream sediments collected before 2003 are characterized by weak weathering intensity, in agreement with the overwhelming flux and fast transfer of sediments derived from the mountainous upper watershed. After the Three Gorges Dam operation, strong midlower riverbed erosion changed the roles of the midlower reaches from important sinks to major sources of sediments delivered to the East China Sea. This resulted in a progressive change of the sediment chemistry because the eroded midlower riverbed sediments were more deeply weathered, as confirmed by 150-year-old sediment cored in the lower mainstream and by mass-balance calculations. This more intensive weathering may be explained by warmer climate and longer water-rock interaction time in the midlower basin. Thus, this study suggests the need to quantify potential bias in weathering intensity and controls caused by damming activity in large river systems.
\end{abstract}

\section{Introduction}

Chemical weathering of silicate rocks plays a critical role in regulating the Earth's climate through the consumption of atmospheric carbon dioxide on geological timescales. Numerous studies have attempted to understand the interactive roles of climatic, tectonic, lithological, and hydrological parameters on chemical weathering process (Bluth \& Kump, 1994; Gaillardet et al., 1999; Gaillardet et al., 1999; Garrels \& Mackenzie, 1971; Gislason et al., 2009; Kump et al., 2000; Louvat \& Allègre, 1997; Maher \& Chamberlain, 2014; Torres et al., 2015; West et al., 2005; Winnick \& Maher, 2018). These studies mainly focused on chemical composition of dissolved and particulate phases of rivers draining large portions of the upper continental crust, from the mountainous valley of headwaters to flat floodplain basins in the midlower reaches. To date, more than $60 \%$ of rivers worldwide longer than $1,000 \mathrm{~km}$ are strongly affected by human activities, especially by intense dam constructions (Dynesius \& Nilsson, 1994; Grill et al., 2019; Syvitski et al., 2005). However, the impacts of these dams on downstream sediment chemistry remain poorly known, which hinders our understanding of continental weathering controls at large scale.

As the largest river in China, the Changjiang (Yangtze River) historically transported about $470 \mathrm{Mt} / \mathrm{year}$ sediments into the marginal sea (Milliman \& Farnsworth, 2013), which represents approximately $2.5 \%$ of the present-day estimate for the global sediment flux. The annual flux of total dissolved solids from the Changjiang is about $1.54 \times 10^{8}$ tons, placing it as the second highest in the world just after the Amazon River (Chen et al., 2002; Gaillardet, Dupré, Louvat, \& Allegre, 1999; Moon et al., 2014). The study of weathering and erosion processes in the Changjiang catchment is therefore of great significance for better understanding continental weathering and material cycling from a global perspective. However, the Changjiang basin is one of the most populated areas in the world, with 15-20\% of total dissolved solids coming from anthropogenic inputs (Chetelat et al., 2008). In particular, more than 50,000 dams have been constructed within the catchment (Changjiang Water Resources Commission, 2002-2016), among 
which the Three Gorges Dam (TGD) is the world's largest hydroelectric engineering project (Yang et al., 2014). These dams have largely disturbed the natural sediment "source-to-sink" systems, with more than $80 \%$ of sediments derived from the Himalaya mountains and the Tibetan Plateau (Figure 1a), being retained efficiently in these reservoirs (Yang et al., 2006; Yang et al., 2014). Sediment-transport patterns in the downstream of the TGD also changed from transport-deposition balance to net riverbed erosion. This pattern changed because the sediment-carrying capacity of downstream water flow exceeded the supply of suspended material (Chen et al., 2010; Lai et al., 2017; Luo et al., 2012). In addition, Wang et al. (2018) reported increased dissolved Si flux in the lower mainstream in recent years and attributed it to increased flux of biogenic silica redissolution in response to the riverbed erosion downstream of the TGD.

Generally, silicate weathering in the Changiiang basin displays great spatial heterogeneity and is primarily driven by monsoonal climate, while provenance lithology plays a subordinate role (Yang et al., 2004). The upper reaches are overall featured by a weathering-limited regime with significant physical erosion in the eastern Tibet, while the midlower reaches are characterized by a transport-limited regime because of its stable tectonics and gentle relief as well as warmer and wetter climate (Bi et al., 2015). Recent studies suggested that the floodplain weathering in the Changjiang basin was likely not significant before the TGD operation. For instance, the averages of Chemical Index of Alteration estimated from the sediments sampled in the upper reaches and at the river mouth were not significantly different (Yang et al., 2004, 2013), which implies a weak chemical alteration during the sediment source-to-sink transport. In addition, Chetelat et al. (2013) found that the suspended sediments sampled in 2006 from the midlower reaches likely experienced similar extent of chemical weathering compared with that from the upper reaches. These observations seemingly question the importance of floodplain weathering in the Changjiang basin. To our knowledge, the floodplain, colluvial, and alluvial plains (mostly $<500 \mathrm{~m}$ in altitude) are well developed in the midlower Changjiang valley, occupying about $44 \%$ of the total catchment area.

To date, the influence of TGD construction on weathering signal propagation in the Changiang basin is less constrained. Most previous studies focused on studying the role of lithology and climate on weathering intensity registered in river sediments. Moreover, their sampling scopes were limited. In order to verify the role of floodplain weathering in the midlower Changjiang valley and if the TGD construction has altered the chemistry of downstream sediment, this study investigates the temporal variations of elemental compositions of suspended particulate matter (SPM), riverbed sand (RBS), bank sediments, and core samples collected downstream of the TGD. By comparing our results with literature data for sediments collected from the whole river system over the last two decades, we confirm a significant downstream temporal variation of sediment-weathering intensity and highlight the potential impact of the TGD on altering dissolved element fluxes to the East China Sea.

\section{River Setting}

The Changjiang is the largest river in Asia and the third longest river in the world. It is more than 6,300 $\mathrm{km}$ long and has a catchment area of $1.8 \times 10^{6} \mathrm{~km}^{2}$. In terms of water discharge and sediment flux, the Changjiang River transports nearly $900 \mathrm{~km}^{3} /$ year and $470 \mathrm{Mt} /$ year to the East China Sea (Milliman \& Farnsworth, 2013). According to hydrological and geographic settings, the Changjiang drainage basin is generally divided into three sections (Figure 1a). The upper reaches indicate the portion from the headwater to Yichang city with 4,500 km in channel length. The middle reaches are $950 \mathrm{~km}$ long, running from Yichang to Hukou city. The lower reaches extend from Hukou to the river mouth with a length of about $850 \mathrm{~km}$. The Changiiang catchment is dominated by the East Asia monsoon climate, with the rainfall belt occurring in the midlower basin between March and June and then gradually migrating to the upper basin starting in July (Chen et al., 2010; Yang et al., 2013). The annual average precipitation over the whole basin is $\sim 1,100 \mathrm{~mm}$, ranging from 150 to 1,000 $\mathrm{mm}$ in the upper basin and averaging 1,200 $\mathrm{mm}$ in the midlower basin (Chen et al., 2010). More than $60 \%$ of the annual precipitation falls during the wet season from May to October (Changjiang Water Resources Commission, 2002-2016). Correspondingly, water discharge during the wet season accounts for $60-70 \%$ of its total water discharge. Geographically, the upper watershed features active tectonics and steep mountains, especially in the Jinshajiang valley, with an elevation above 3,500 $\mathrm{m}$. The elevations of middle and lower reaches are mostly below $500 \mathrm{~m}$, and floodplains and lakes are widely distributed. 

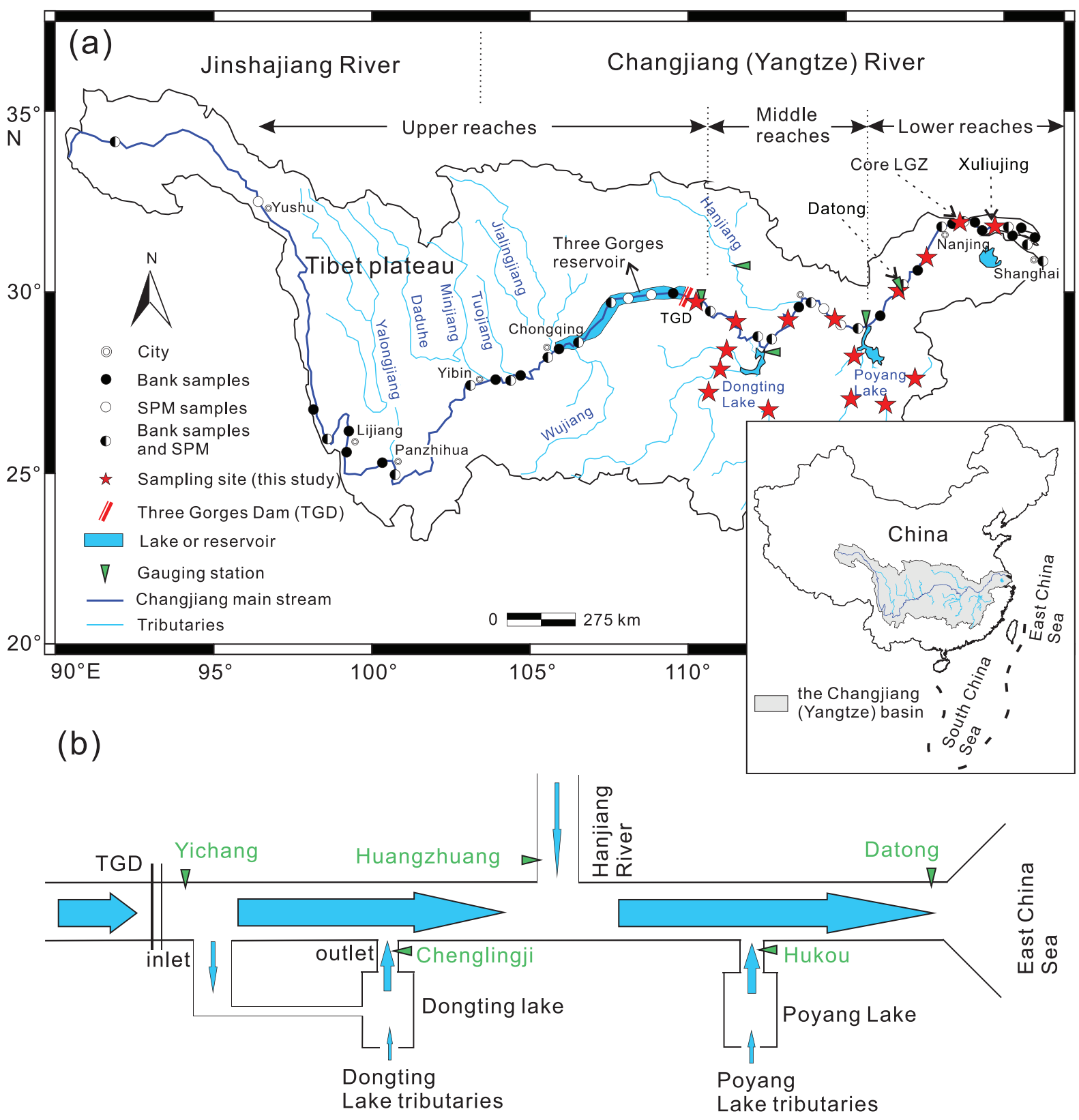

Figure 1. (a) Schematic map showing the Changjiang drainage basin and (b) a cartoon showing the relative position of tributaries, lakes, and gauging stations. Red stars display sampling sites of this study, and circles represent sampling sites for data collected from literatures (Ding et al., 2014; He et al., 2015; Yang et al., 2004, 2013). TGD = Three Gorges Dam.

The TGD is located $40 \mathrm{~km}$ upstream of Yichang city, which is considered to be the boundary between the upper and middle reaches. The elevation of the TGD is $185 \mathrm{~m}$ above the sea level. Impoundment of water began in June 2003 and started its full operation since 2009. Currently, the Three Gorges Reservoir covers upstream river channel over a distance of $660 \mathrm{~km}$ (Figure 1a). The storage capacity of the reservoir is designed to be $39.3 \mathrm{~km}^{3}$, and the water level within the reservoir fluctuates seasonally by $30 \mathrm{~m}$ between 145 and $175 \mathrm{~m}$ for flood control (Yang et al., 2014). According to records at Datong (Figure 1), which is the most seaward gauging station without tidal influence, the sediment flux has decreased from $430 \mathrm{Mt} /$ year between 1950s and 2002 to $152 \mathrm{Mt} / \mathrm{year}$ in 2016 (Changjiang Water Resources Commission, 2002-2016). 


\section{Materials and Methods}

\subsection{Sample Collection}

A total of 18 SPM samples were collected in wet season (i.e., June, August, and October) of 2014 at Xuliujing gauging station, approximately $100 \mathrm{~km}$ landward from the river mouth (Figure 1a). The average water depth at Xuliujing during the sampling period was $50 \mathrm{~m}$. For each month, six SPM samples were collected along a vertical profile from 0 to $50 \mathrm{~m}$ in depth with a sampling interval of $10 \mathrm{~m}$. Generally, about 50-L river water was drawn for each sampling and filtered on-site through a $0.45-\mu \mathrm{m}$ membrane of cellulose acetate later to collect particulate matter. The river bank sediment samples were collected within the midlower basin in May 2018, including nine from the Changjiang mainstream, five from the Dongting Lake tributaries, seven from the Poyang Lake tributaries, and two from the Hanjiang river (Figure 1a). A total of five RBS samples were collected by ship-based grab sampler in 2010 and 2011 at Datong gauging station, $600 \mathrm{~km}$ landward of the river mouth. Core LGZ (Leigongzui), 2-m long, was collected in the central bar at the lower Changjiang mainstream in 2008 ( $\left.33^{\circ} 18^{\prime} 393^{\prime \prime} \mathrm{N}, 119^{\circ} 45^{\prime} 218^{\prime \prime} \mathrm{E}\right)$, about $150 \mathrm{~km}$ upstream of the river mouth (Figure 1a). The core was split and subsampled at 2-cm intervals and stored in the State Key Laboratory of Marine Geology since 2008. The depositional age of bottom sediments can date back to about 150 years ago, based on the ${ }^{210} \mathrm{~Pb}$ geochronology (Zhan et al., 2010). In this study, only 16 samples were taken throughout Core LGZ for major-element analyses, with average temporal resolution of $\sim 10$ years. All of these samples were dried to constant weight at $40{ }^{\circ} \mathrm{C}$ temperature in the laboratory.

In this study, the published data are also complied in order to thoroughly investigate weathering signal changes. These samples include bank sediments collected in 1997 (Yang et al., 2004) and 2003 (Yang et al., 2013), SPM collected between 2003 and 2007 (Ding et al., 2014), and fine-grained $(<63 \mu \mathrm{m})$ sediments collected in 2009 (He et al., 2015).

\subsection{Major-Element Analyses}

In this study, the SPM and RBS samples were analyzed for major elements by Inductively Coupled PlasmaOptical Emission Spectrometers (ICP-OES, model: IRIS Advantage), and the bank sediment and core samples were analyzed by X-ray fluorescence (XRF, model: AXIOSmAX). The instrument precisions are better than $1 \%$ for XRF and $0.5 \%$ for ICP-OES. These analyses were conducted in the State Key Laboratory of Marine Geology at Tongji University.

About $1 \mathrm{~g}$ of each sample was ground in an agate mortar and then ignited in a muffle furnace at $600{ }^{\circ} \mathrm{C}$ in order to weigh loss of ignition and remove organic matter before acid digestion. In order to verify a potential bias related to the sample pretreatment, we selected six SPM samples and treated them with 1M HCl following the method of Bi et al. (2015), while all other data come from untreated samples. The objective of the $1 \mathrm{M}$ $\mathrm{HCl}$ treatment was to remove the carbonate fraction. For the ICP-OES measurement, about 50-mg powder samples were dissolved with a mixture of $1: 1$ concentrated $\mathrm{HNO}_{3}$ and $\mathrm{HF}$ in a tightly closed Teflon vessel for at least $48 \mathrm{hr}$ at $190{ }^{\circ} \mathrm{C}$. After drying, samples were redissolved in $\mathrm{HNO}_{3}$ to remove any fluorides. Finally, samples were redigested in $2 \mathrm{ml} 30 \% \mathrm{HNO}_{3}$ at $190{ }^{\circ} \mathrm{C}$. The Si concentration was obtained by assuming the total content of major oxide and trace elements in the residues is $100 \%$, following the calculation method of Guo et al. (2018). The errors of calculated Si concentration are less than $8 \%$. For the XRF method, the powder samples were directly fused with lithium tetraborate $\left(\mathrm{Li}_{2} \mathrm{~B}_{4} \mathrm{O}_{7}\right)$ at $1,050{ }^{\circ} \mathrm{C}$ to make a glass disk for the XRF measurement. The analytic precision and accuracy were monitored by the simultaneously processed standards of BCR-2 for ICP-OES and GSR-3 for XRF. The results showed that the accuracy of major element is generally better than $5 \%$ and the precision (one standard deviation) is better than $1 \%$.

\subsection{Chemical Weathering Proxy}

As suggested by Lupker et al. (2012), the diagram of ratios of major element (Me) to $\mathrm{Si}(\mathrm{Me} / \mathrm{Si}, Y$ axis) versus $\mathrm{Al} / \mathrm{Si}$ ( $X$ axis) can be used to discriminate hydrodynamic sorting and silicate weathering (i.e., leaching) intensity. Mineral and grain size sorting can be recognized by a mixing trend, showing higher $\mathrm{Al} / \mathrm{Si}$ ratios in finer sediments enriched in clays and lower $\mathrm{Al} / \mathrm{Si}$ ratios in coarser sediments enriched in quartz. In contrast, change of weathering intensity is discerned by a vertical trend, showing a decrease of mobile element/Si ratio (caused by leaching) at constant $\mathrm{Al} / \mathrm{Si}$. In the following, the temporal variability of element/Si ratio means the comparison is done at a given $\mathrm{Al} / \mathrm{Si}$ ratio. 


\subsection{Monte Carlo Simulation}

In order to calculate the elemental ratio (i.e., $\mathrm{K} / \mathrm{Si}$ and $\mathrm{Al} / \mathrm{Si}$ ratio) variations of midlower riverbed sediments and compare them with the data measured in the sediment core (see section 5), a Monte Carlo simulation was developed. Briefly, the sources of Changjiang sediments into the East China Sea mainly come from five end-members: upper reaches, Dongting Lake, Poyang Lake, Hanjiang River, and midlower riverbed (Yang et al., 2018). The ranges of elemental ratios for the first four end-members are published (Ding et al., 2014). Based on simple mass balance equations, the elemental ratios for midlower riverbed sediments can be simulated, with an assumption of conservative elemental behavior during transport and mixing. The Monte Carlo simulation was performed with MATLAB 2018a software. The detailed description is provided in Text $\mathrm{S} 1$ in the supporting information.

\section{Results}

The Al/Si ratios of Xuliujing SPM samples range from 0.2 to 0.4 (Figure 2), within the reported range of SPM samples collected in the Changjiang mainstream (Ding et al., 2014). The Al/Si ratios of samples from Core LGZ range from 0.28 to 0.45 (Table S4), reflecting enrichment of fine-grained materials. The grain size of core samples reflected by $\mathrm{Al} / \mathrm{Si}$ ratios is similar to that of SPM. Relative to the SPM and core samples, the $\mathrm{Al} / \mathrm{Si}$ ratios of RBS samples show apparent lower values and narrow variation, ranging from 0.1 to 0.15 . The mobile elements, that is, $\mathrm{K}, \mathrm{Na}, \mathrm{Ca}$, and $\mathrm{Mg}$, display different mobility, with lower $\mathrm{K} / \mathrm{Si}, \mathrm{Ca} / \mathrm{Si}$, and $\mathrm{Mg} / \mathrm{Si}$ ratios but higher $\mathrm{Na} / \mathrm{Si}$ ratios in the $\mathrm{RBS}$ relative to the SPM. As a function of $\mathrm{Al} / \mathrm{Si}$ ratios, $\mathrm{SPM} \mathrm{K} / \mathrm{Si}$ and $\mathrm{Mg} / \mathrm{Si}$ ratios increase from 0.06 to 0.10 and from 0.04 to 0.06 , respectively (Figures $2 \mathrm{a}$ and $2 \mathrm{~d}$ ). In contrast, SPM Na/Si and $\mathrm{Ca} / \mathrm{Si}$ ratios decrease from 0.04 to 0.02 and from 0.10 to 0.07 , respectively (Figures $2 \mathrm{~b}$ and $2 \mathrm{c}$ ). In Core LGZ, the $\mathrm{K} / \mathrm{Si}$ ratios range from 0.05 to 0.10 , similar to that measured in the SPM samples (Table S4). The different variation trends among $\mathrm{K}, \mathrm{Na}, \mathrm{Mg}$, and $\mathrm{Ca}$ are possibly related to their respective behaviors during clay formation. $\mathrm{K}$ and $\mathrm{Mg}$ can be reincorporated into illite and smectite, while $\mathrm{Na}$ and $\mathrm{Ca}$ are preferentially leached during chemical weathering (He et al., 2013).

A linear correlation exists between $\mathrm{K} / \mathrm{Si}$ and $\mathrm{Al} / \mathrm{Si}$ ratios for the coarse-grained $\mathrm{RBS}$ and the fine-grained SPM (Figure 2a) and for the core samples as well (Figure 7b). For other mobile elements, the relationship is nonlinear or nonexistent. After 1-M acid pretreatment, apart from $\mathrm{K}$, other mobile elements show apparently lower $\mathrm{Me} / \mathrm{Si}$ ratios for a given $\mathrm{Al} / \mathrm{Si}$ ratio, especially for $\mathrm{Ca}$ and $\mathrm{Mg}$. A significant part of $\mathrm{Ca}$ and $\mathrm{Mg}$ are concentrated in the carbonate and dolomite minerals. After the 1-M HCl pretreatment, $\mathrm{Na} / \mathrm{Si}, \mathrm{Ca} / \mathrm{Si}$, and $\mathrm{Mg} / \mathrm{Si}$ ratios decreased by $0.002,0.07$, and 0.03 , respectively (Table S2). Compared to $\mathrm{Na} / \mathrm{Si}$ and $\mathrm{Mg} / \mathrm{Si}$, $\mathrm{Ca} / \mathrm{Si}$ ratios of decarbonated sediments are homogeneous with an average below 0.02 (Figures $2 \mathrm{~b}$ and $2 \mathrm{c}$ ). The slope of the linear relationship between $\mathrm{K} / \mathrm{Si}$ versus $\mathrm{Al} / \mathrm{Si}$ (Figure 2a) is not modified by the $\mathrm{HCl}$ pretreatment.

\section{Discussion}

Human activities, especially dam constructions, have long been a concern for their influence on riverine sediment routing system. Dams have been considered as the leading contributors to the disturbance of sediment transport and river connectivity (Dynesius \& Nilsson, 1994; Grill et al., 2019; Syvitski et al., 2005); however, dams' impact on chemical composition of downstream sediment is poorly understood still. Herein, the impact of the TGD construction on river sediment weathering intensity is determined, which provides an important example for the studies of chemical weathering in large river systems during postdam periods worldwide.

\subsection{Mobile Element Variability for the Downstream Sediments}

\subsubsection{Stronger K Leaching Intensity After 2003}

The major-element data we collected cover the period before and after the TGD operation (1997-2018). As illustrated in Figure 3, the compiled data set (2003-2014) plotted in the K/Si vs Al/Si diagram follows two distinct regression lines, with statistically different slopes. $\mathrm{Al} / \mathrm{Si}$ ratios are regarded as a proxy for particulate size and are particularly sensitive to mineral sorting during transport, while K/Si ratios can be used as an index of the leaching intensity of silicates, as described in section 3.3. Sediments collected in rivers draining the upper reaches define a straight line with a strong slope (in blue dash line in Figure 3). This is in agreement with a relatively weak leaching of potassium in fine-grained sediments 

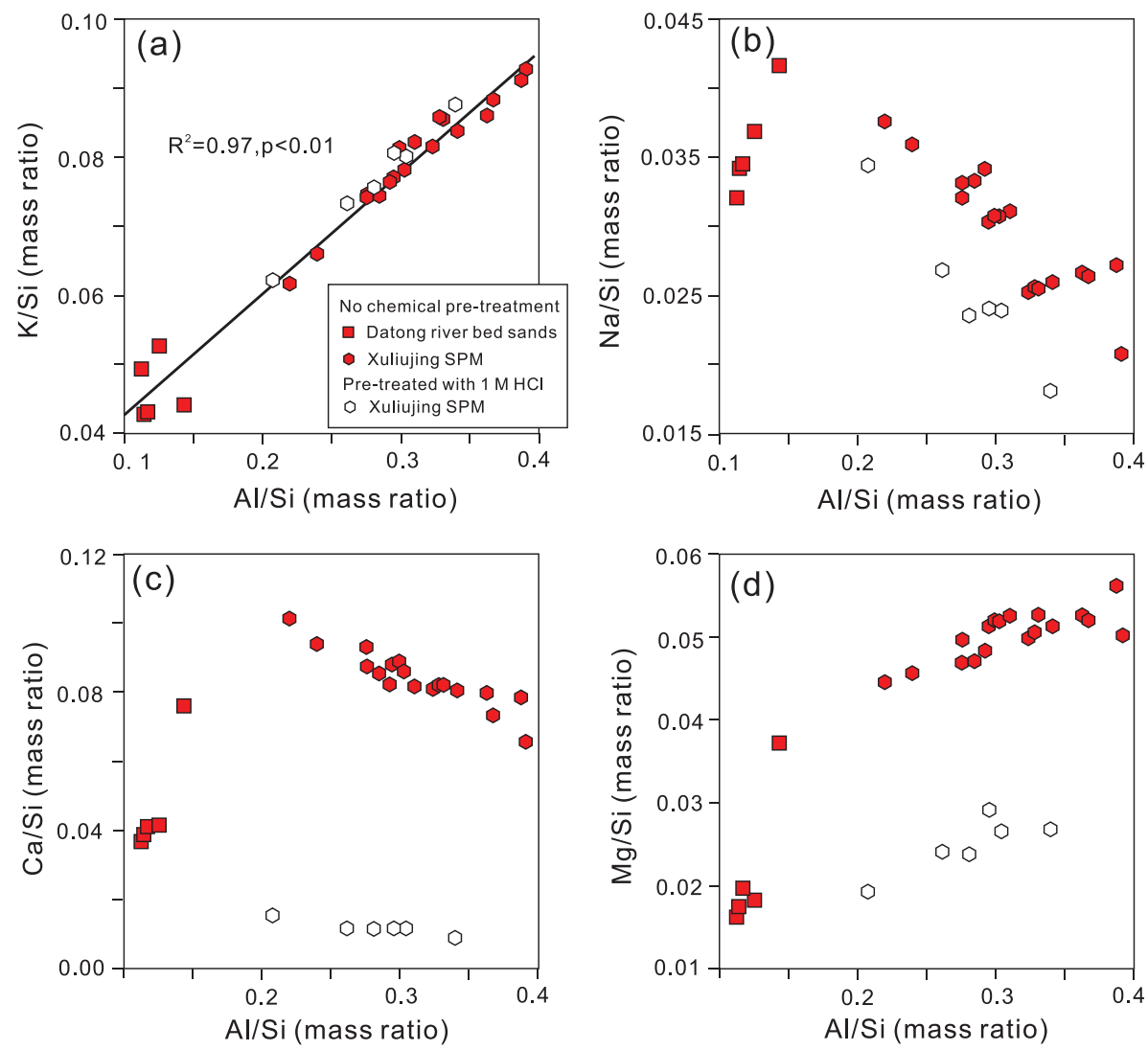

Figure 2. The influence of $1 \mathrm{M} \mathrm{HCl}$ pretreatment on river $\mathrm{SPM}$ and bed sands $\mathrm{K} / \mathrm{Si}$ (a), $\mathrm{Na} / \mathrm{Si}$ (b), $\mathrm{Ca} / \mathrm{Si}$ (c), and $\mathrm{Mg} / \mathrm{Si}(\mathrm{d})$, all reported as a function of $\mathrm{Al} / \mathrm{Si}$, considered as a proxy of grain size effects related to mineral sorting during transport (Lupker et al., 2012). SPM = suspended particulate matter.

(i.e., high $\mathrm{Al} / \mathrm{Si}$ ratio), mostly concentrated in K-bearing silicates of the upper highland rocks and soils. This feature is consistent with weathering-limited conditions in mountainous regions with thin soils, where sediment residence times are short (West et al., 2005). In contrast, data points of river sediments collected downstream of the TGD (in red in Figure 3) define a linear trend with a lower slope, showing a significant depletion in $\mathrm{K}$ compared to sediments collected from the upper reaches albeit with similar $\mathrm{Al} / \mathrm{Si}$ ratios. This observation suggests a stronger weathering (leaching) intensity registered in the sediments collected downstream of the TGD.

Examining in detail the data provided by sediments collected in the midlower mainstream shows that a progressive depletion in $\mathrm{K} / \mathrm{Si}$ can be observed since 2003, that is, the beginning of the TGD operation (Figure 4a). Before 2003, the K/Si ratios of SPM and bank sediments display a weathering intensity that is similar to the one of the upstream-derived sediments (for a given $\mathrm{Al} / \mathrm{Si}$ value). Then, between 2003 and 2007, a progressive and significant depletion of $\mathrm{K}$ (relative to $\mathrm{Si}$ ) is exhibited by the SPM samples from the same river section (see Figure $4 \mathrm{~b}$ ). The Three Gorges Reservoir can be a potential reactor for further weathering by favoring long storage time for the upstream sediments. However, sediments collected from the Three Gorges Reservoir exhibit no change in $\mathrm{K}$ depletion (Figure 3). This implies that the leaching process did not happen upstream of the TGD during the reservoir trapping. The acid rain deposition in the Changjiang basin is mainly constrained in the Chongqing-Guiyang region of the Jinshajiang valley (Chen et al., 2002). No severe atmospheric acid deposition events were reported recently in the midlower basin. We thus infer that the process resulting in SPM K leaching may be related to either continuous leaching in the midlower basin, or to a progressive change of the SPM provenance in response to the TGD operation, or the combined effect of both in the midlower basin. Using hydrological data from the gauging station between 2002 and 2015, it is possible to quantify the various fluxes of sediments coming from several identified sources and verify if a source change can explain this trend. These calculations are presented in section 5.2. 


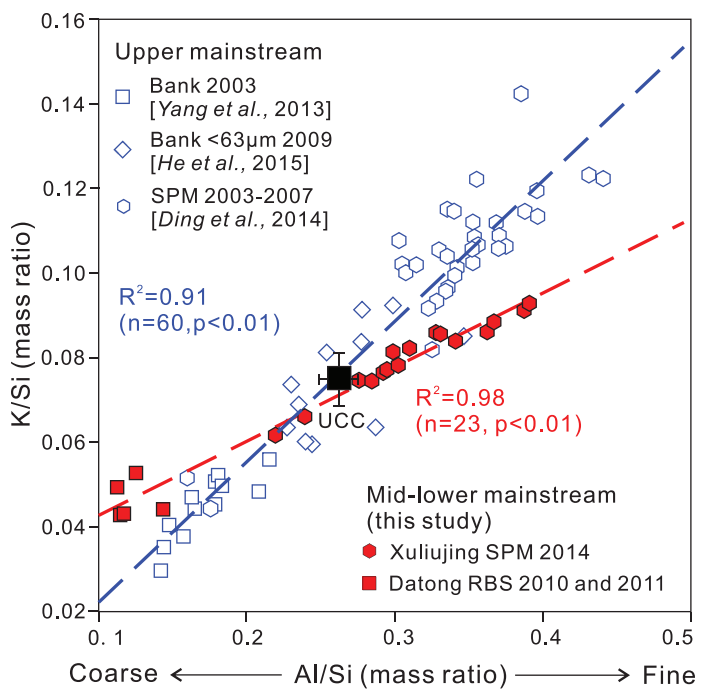

Figure 3. $\mathrm{K} / \mathrm{Si}$ versus $\mathrm{Al} / \mathrm{Si}$ ratios measured for bank sediments and suspended particulate matter of the Changjiang River (mainstream). Sediments collected from the upper reaches (in blue) display a distinct relationship from the midlower reaches (in red). The black square represents the average value of the source rock of the Upper Continental Crust (Rudnick \& Gao, 2003). Major element data of bank sediments, fine-grained $(<63 \mu \mathrm{m})$ sediments and SPM are from Yang et al. (2004, 2013), He et al. (2015), and Ding et al. (2014), respectively. SPM = suspended particulate matter.; RBS = riverbed sand.
It is interesting to note that the mean $\mathrm{K} / \mathrm{Si}$ and $\mathrm{Al} / \mathrm{Si}$ ratios of the Upper Continental Crust (black square) roughly fall between the bank sediments and SPM or fine fractions $(<63 \mu \mathrm{m})$ for both trends (blue and red; see Figure 3). This confirms that the average composition of rocks drained by waters in the large catchment of the Changjiang is representative of the Upper Continental Crust (Yang et al., 2004), thus justifying the use of sediments in large river systems to investigate general information regarding global weathering.

\subsubsection{Large Na Depletion in Fine-Grained Sediments}

In Figure 5, $\mathrm{Na} / \mathrm{Si}$ ratios correlate negatively with $\mathrm{Al} / \mathrm{Si}$ ratios. The $\mathrm{Na}$ concentration in the fine fraction is lower and yields higher values in coarse grains. The downward $\mathrm{Na} / \mathrm{Si}$ variation as a function of $\mathrm{Al} / \mathrm{Si}$ for $\mathrm{SPM}$ reflects weathering of bedrock, as $\mathrm{Na}$ is hard to be incorporated into secondary phases, in contrast to $\mathrm{K}$. The range of $\mathrm{Al} / \mathrm{Si}$ ratios measured in the upstream-derived and the midlower mainstream SPM are similar. Nevertheless, $\mathrm{Na} / \mathrm{Si}$ ratios are slightly lower for the midlower mainstream SPM (Figure 5). In contrast to $\mathrm{K} / \mathrm{Si}$, no temporal trend can be clearly observed for $\mathrm{Na} / \mathrm{Si}$ ratios of the midlower mainstream SPM between 2003 and 2014 (Figures 3-5). This is likely due to the strong Na leaching in the upper basin, resulting in very low $\mathrm{Na} / \mathrm{Si}$ ratios in the highest $\mathrm{Al} / \mathrm{Si}$ ratio of SPM. Thus, the large Na depletion of finest sediments due to its high mobility and incompatibility with secondary phases precludes any precise observation about SPM Na/Si temporal variation.

\subsection{Significant Impact of TGD on the Sediment Source-to-Sink Process}

The midlower Changjiang basin is one of the most populated areas of the world. In this region, most parts of the river are constrained by artificial embankment. This means that the direct sediment contribution from nearby floodplain is limited. Bank sediments mainly come from the deposition of river suspended load, as shown by numerous studies and observations (Maharana et al., 2018). Previous studies (Chen et al., 2010; Guo, Su, et al., 2018; Yang et al., 2006) have shown that the major sources of Changjiang sediments into the East China Sea include the upper reaches, Dongting Lake, Hanjiang River, Poyang Lake, and midlower riverbed (Figure 1b). The Dongting and Poyang lakes are located downstream of the TGD and have received a huge amount of sediment derived from the upper reaches before the TGD operation in 2003. Thus, the lakes as well as the midlower riverbed were important depositional sinks for upstream-derived Changjiang sediments (Chen et al., 2010; Guo et al., 2018). However, with the TGD impoundment in 2003, these two lakes and the midlower riverbed have undergone serious erosion and thus shifted to important sources of sediments into the East China Sea (Guo, Su, et al., 2018; Luo et al., 2012; Yang et al., 2006; Yang et al., 2014).

In order to investigate further these aspects, a more quantitative approach can be applied using monitored sediment flux (Figure 6 and Table S5). As illustrated by the hydrological observations at Datong gauging station between 2002 and 2015 (Figure 6a), the Changjiang water discharge was relatively constant during this period. The sediment flux decreased steadily since 2003 and became relatively constant after 2006, mainly because of the balance between significant trapping of upstream-derived sediments by the TGD and sediment supply from the midlower reaches. This change resulted in downstream sediment concentration lower than sediment carrying capacity, leading to a visible physical erosion within the Dongting Lake and within the midlower riverbed (Lai et al., 2017).

Following previous studies (Yang et al., 2006; Yang et al., 2018), the monitored sediment flux at Datong, Yichang, Huangzhuang, Chenglingii, and Hukou gauging stations (Figure 1b) represents the total sediment flux into the East China Sea $\left(F_{T}\right)$, sediment flux from the upper reaches $\left(F_{U}\right)$, the Hanjiang River $\left(F_{H}\right)$, the Dongting Lake $\left(F_{D}\right)$, and the Poyang Lake $\left(F_{P}\right)$, respectively (Changjiang Water Resources Commission, 2002-2016). Then, the midlower riverbed sediment flux $\left(F_{E}\right)$ can be estimated using equation (1) below, with assumption of a conservative mixing (Table S5). Then, we can estimate the relative sediment contributions of these five sources to total sediment flux $\left(F_{X} / F_{T}\right.$, X represents sediment source). 

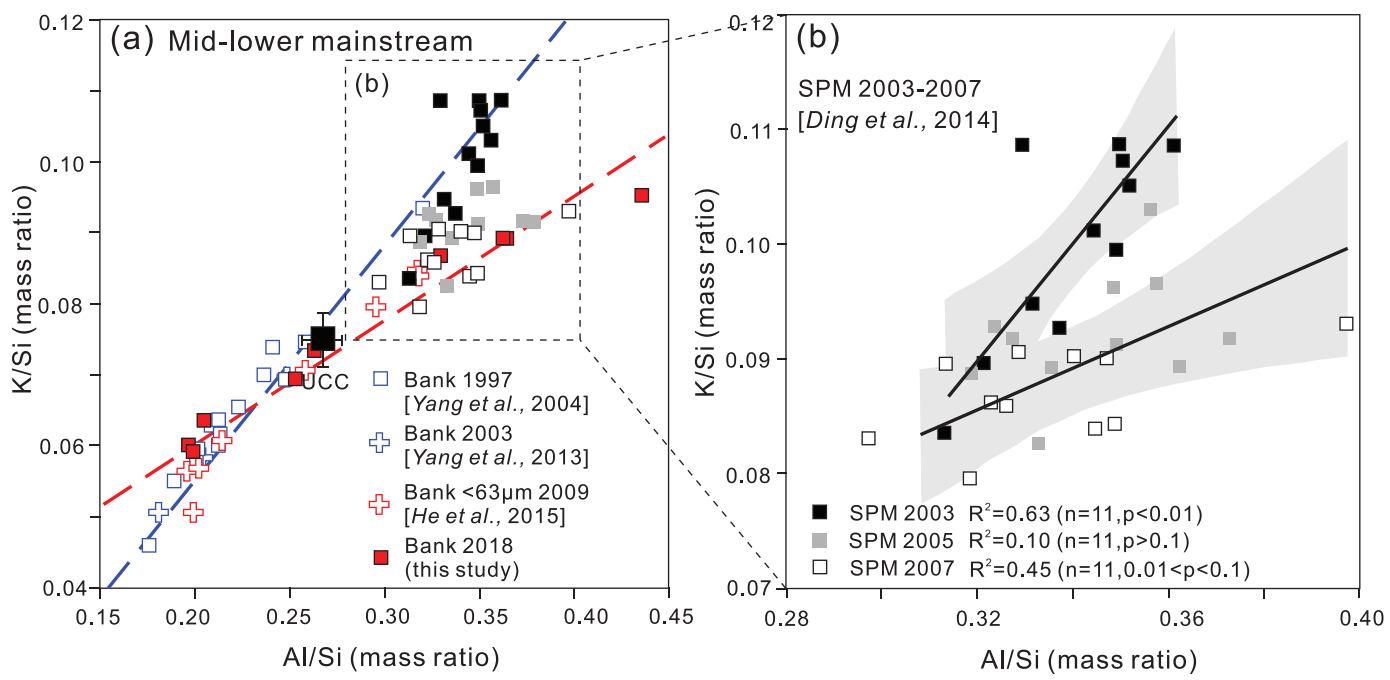

Figure 4. $\mathrm{K} / \mathrm{Si}$ versus $\mathrm{Al} / \mathrm{Si}$ ratios measured for bank sediments and SPM sampled from the midlower Changjiang River (mainstream). (a) Between the time of the TGD operation and 2014, SPM and bank sediments from the midlower reaches (downstream of the Dam) display a progressive depletion in $\mathrm{K}$ (compared to $\mathrm{Si}$ ). (b) $\mathrm{K} / \mathrm{Si}$ versus $\mathrm{Al} / \mathrm{Si}$ for $\mathrm{SPM}$ collected in the midlower reaches mainstream of the Changjiang Basin (Ding et al., 2014). The statistical test for SPM collected in 2005 is insignificant, and the best-fits line is not shown. SPM = suspended particulate matter.

$$
F_{T}=F_{U}+F_{D}+F_{H}+\mathrm{F}_{\mathrm{P}}+\mathrm{F}_{\mathrm{E}}
$$

Results show that the upper reaches dominated the source of sediments into the East China Sea before the TGD operation, with a proportion up to $83 \%$ in 2002 (Figure 6b). Since the TGD impoundment in 2003, the relative contribution of upstream-derived sediment decreased rapidly, especially by 2015 when almost all of the upstream-derived sediment was trapped upstream of the TGD. In contrast, the proportion of sediments eroded from the midlower riverbed rapidly increased from $~ 17 \%$ in 2002 to $30 \%$ in 2003 and then to $\sim 50 \%$ after the TGD in full operation (2009-2012) and finally increased to nearly $65 \%$ after cascade dams operated on the Jinshajiang River since 2013 (Figure 6b). As described above and in Figure 6b, the midlower riverbed erosion is mostly related to sediment carrying capacity of river flow exceeding suspended material concentration. We also estimate that the relative contributions of Dongting and Poyang Lakes increased by nearly $\sim 20 \%$ and $\sim 5 \%$, respectively. The sediment contribution from the Hanjiang River did not show significant variation during this period ( $<6 \%$; Figure $6 \mathrm{c}$ ). Note that parts of upstream-derived sediment are transported into the Dongting Lake through three inlets downstream of the Yichang gauging station (Figure 1b), the sediment flux monitored in Yichang gauging station therefore represents the maximum flux of upstream-derived sediment $\left(F_{U}\right)$. Considering progressively decreased flux of upstream-derived sediment and of sediments into the Dongting Lake since 2003 (Guo, Su, et al., 2018), we estimate this bias to the calculation above is minor.

\subsection{Possible Mechanism Responsible for Downstream Weathering Signal Variations}

As discussed above, the relative proportions of sediment contributions from the Poyang Lake, Dongting Lake, and midlower riverbed increased by about 5\%, 20\%, and 40\%, respectively, during the observation period (2002-2015; Figures 6b and 6c). Sediment source changes may account for the change of the downstream $\mathrm{K}$ leaching signal. Previous studies indicated that the kaolinite content of the Poyang Lake-derived sediments increased, while the dissolved load was also enriched in Si after the TGD construction (Wang et al., 2018; Zhao et al., 2018). However, our results are in contrast to this hypothesis since the sediments collected in the Poyang Lake in 2018 are characterized by a similar weathering intensity as for samples collected during the previous periods (Figure 7a). Compiled altogether, these data show that the weathering signal, at least for $\mathrm{K} / \mathrm{Si}$ ratios, did not change significantly in sediments collected from the Poyang Lake basin during the last decades (Figure 7a). Thus, a slightly increased proportion of sediments from Poyang Lake (Figure 6c) cannot explain the significant K depletion of the Changjiang SPM in the lower basin. 


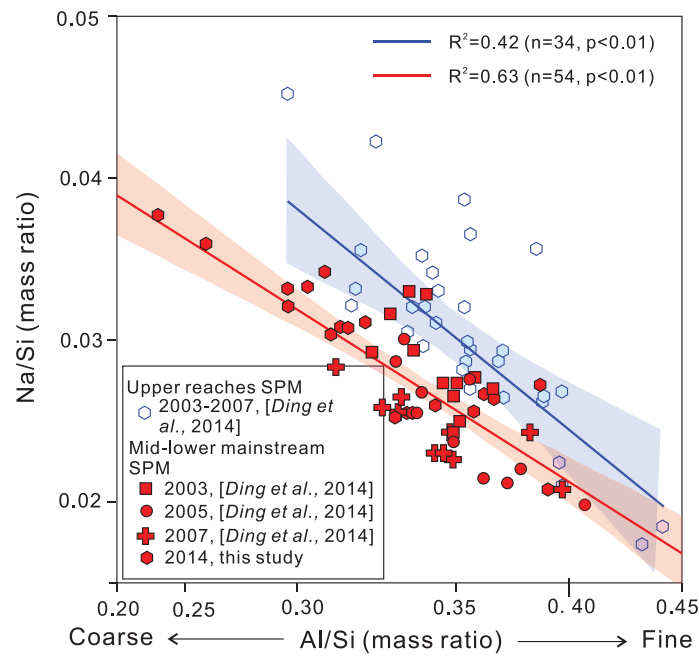

Figure 5. $\mathrm{Na} / \mathrm{Si}$ versus $\mathrm{Al} / \mathrm{Si}$ ratios measured for riverbed sands and SPM of the Changjiang River (mainstream). Because there is a discrepancy for $\mathrm{Na} / \mathrm{Si}$ ratios between different acid pretreatment, only data of samples without acid pretreatment are displayed here. SPM = suspended particulate matter.
The Dongting Lake was identified as a sediment sink before the TGD operation, receiving a large amount of sediments from its four tributaries and from the Changjiang upstream as well (Guo, $\mathrm{Su}$, et al., 2018). After the TGD operation, Dongting Lake gradually changed from a major sink of upstream-derived sediment to a source of sediments into the East China Sea (Guo, Su, et al., 2018). As illustrated in Figure $7 \mathrm{a}$, the sediments from the Dongting Lake tributaries show a lower $\mathrm{K} / \mathrm{Si}$ ratio, in contrast to data of upstream-derived sediments. In that sense, the weathering signal of sediments from the Dongting Lake is primarily determined by two sources, that is, strongly weathered sediments from its tributaries and weakly weathered sediments from the Changjiang upper reaches. Interestingly, the sediments collected in the Dongting Lake outlet (i.e., the one that contribute to the Changjiang River) show a weak weathering intensity and have a chemical composition close to that of the sediment derived from the upper reaches (see Figure 7a). This can be easily interpreted using hydrological data (Guo, Su, et al., 2018), as the average annual sediment flux from its low-land tributaries $(35.2 \pm 23.5 \mathrm{Mt} /$ year in 1953-1984) is much smaller than the one from the Changjiang upper reaches (200.2 $\pm 59.4 \mathrm{Mt} /$ year in 1956-1968). Thus, the Dongting Lake is mostly fed by weakly weathered sediments derived from the upper Changjiang. Furthermore, in comparison with pre-TGD period, the kaolinite concentration $(\sim 30 \%)$ in Dongting Lake remains constant (Zhao et al., 2018), and the dissolved Si flux even decreased from $0.76 \times 10^{6}$ t/year in 1958-2002 to $0.67 \times 10^{6}$ t/year in 2003-2014 (Wang et al., 2018). All of those observations suggest that the outflowing Dongting Lake sediments are characterized by weak weathering intensity (i.e., high $\mathrm{K} / \mathrm{Si}$ ratio). Therefore, we infer that sediments from Dongting Lake have no significant influence on the downstream weathering signal change, despite its $20 \%$ increase of relative sediment contribution after 2003.

Given these findings, the most possible explanation would be that midlower riverbed sediments, which deposited downstream before the TGD operation, have been subjected to significant physical and chemical erosion. Otherwise, the weathering signal would have remained constant, because the midlower riverbed sediments primarily originate from the upper reaches (Xu \& Milliman, 2009; Yang et al., 2006; Yang et al., 2018). The correlations between $\mathrm{K} / \mathrm{Si}$ and $\mathrm{Al} / \mathrm{Si}$ for eroded midlower riverbed sediments were analyzed using Monte Carlo simulations in order to identify whether or not the data are compatible with strong potassium depletion of these phases (see the supporting information). As illustrated in Figure $7 \mathrm{~b}$, $\mathrm{K} / \mathrm{Si}$ versus $\mathrm{Al} / \mathrm{Si}$ values of midlower riverbed sediments show an intensified $\mathrm{K}$ leaching, which is consistent with our data from SPM and bank sediments. As illustrated in Figure 4a, the bank sediments sampled downstream of the TGD also show different chemical composition before and after 2003. In 1997 and 2003, they plot along the upper-reaches trend (in blue in Figure 4a), while between 2009 and 2018 they display stronger weathering signals (in red). Therefore, the onset of the TGD impoundment in 2003 seems to be a threshold.

As illustrated in Figure $6 \mathrm{~b}$, the relative proportion of midlower riverbed sediments is estimated to be $\sim 30 \%$ of the total sediment flux in 2003. However, the corresponding data from midlower mainstream bank sediments still plot along the upper-reaches trend in Figure 4a. Our simulated trend in Figure $7 \mathrm{~b}$ also plot very close to the upper-reaches trend, with fine fractions displaying weak weathering degree. This implies that the $\mathrm{K}$ depletion process is significant in the deep sediment layers and there was not enough time for more superficial recently deposited sediments to release K. The data from Core LGZ demonstrate that the sediments with longer depositional age do provide a higher weathering intensity because sediments exhibit lower $\mathrm{K} / \mathrm{Si}$ ratios (Figure $7 \mathrm{~b}$ ). Because the midlower riverbed sediments are primarily derived from the upper reaches, these data strongly support the interpretation that the weathering occurred in situ in the midlower riverbed. This reinforces our hypothesis of more significant contribution from midlower riverbed sediments for explaining the shift of the weathering signal observed after 2003. More intensive weathering of sediments deposited in the midlower reaches is consistent with recent work on the Ganga Basin, indicating that floodplains play a significant role in weathering of K-bearing silicates (Lupker et al., 2012). 


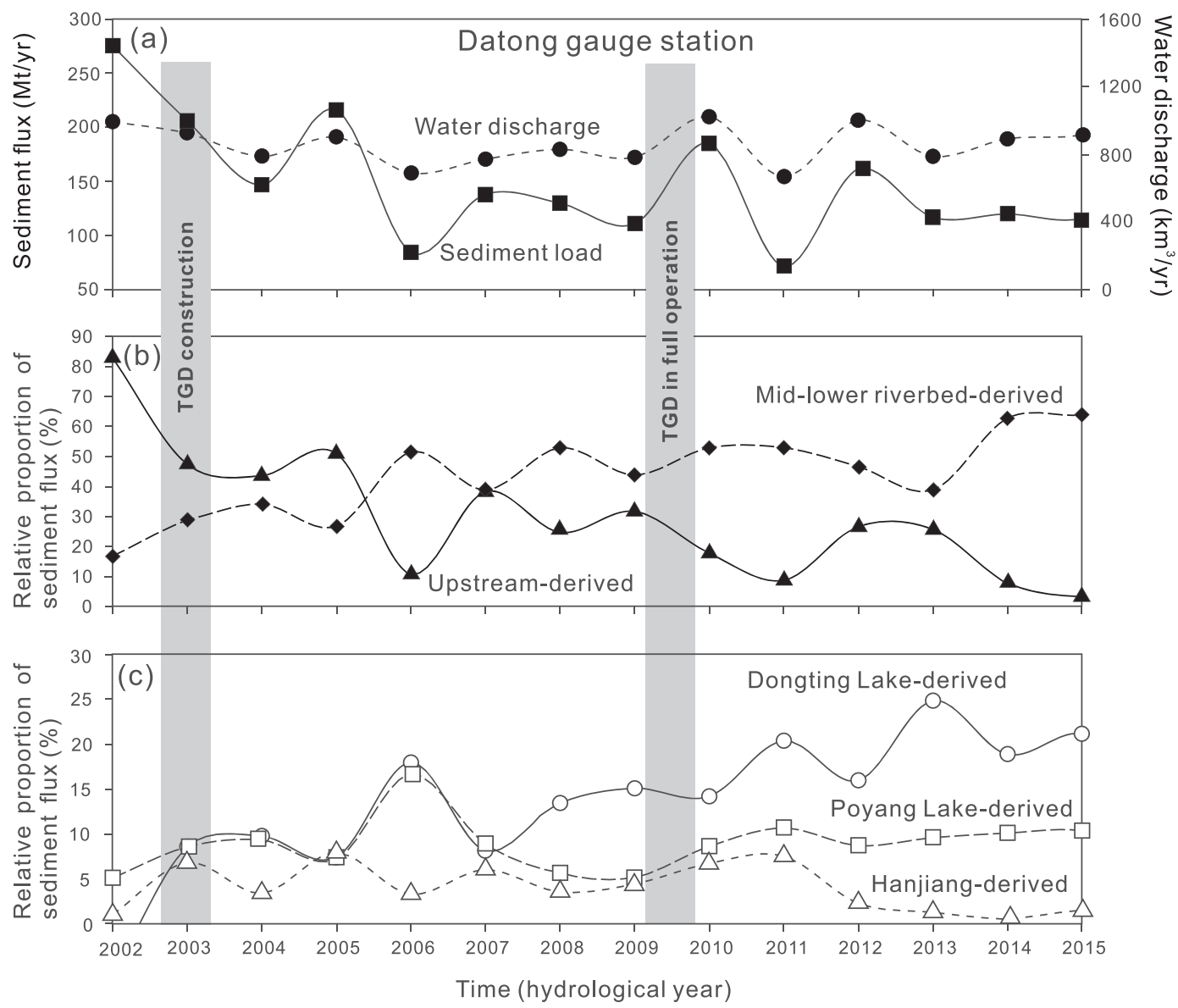

Figure 6. (a) Water discharge and sediment flux as a function of time recorded at the Datong Gauging Station, located in the lower reaches (see Figure 1). The sediment flux significantly decreased with time since the Three Gorges Dam operation, but the water discharge was little affected. (b and c) Relative contribution of the different sources of sediments to the total load. The data of water discharge and sediment flux were collected from the Changjiang Water Resources Commission website (http://www.cjw.com.cn/).

We propose a conceptual model for how the TGD construction affects sediment source-to-sink processes and the related weathering signal propagation in the downstream Changiiang sediments (Figure 8). Before the TGD operation, parts of upstream-derived sediments deposited continuously in the midlower reaches (lakes, floodplain, and riverbed), in response to higher suspended material concentration than sediment carrying capacity of the water flow. These newly deposited sediments overlay the older sediments, masking the floodplain weathering signal (Figure 8a). In 2002, for the first time, the sediment flux at Datong exceeded that at Yichang, reflecting the beginning of net riverbed erosion in the midlower reaches (Xu \& Milliman, 2009). However, the relative proportion of upstream-derived sediment was still dominant, with contribution reaching 83\% (Figure 6b). Additionally, sediments eroded from the midlower riverbed were newly deposited with weak weathering intensity at that time (Figure 7b). Consequently, enhanced weathering signals in midlower reaches could not be observed, despite existence of downstream net riverbed erosion before the TGD operation. However, the scenario changed after the 2003, when the TGD effectively trapped a huge amount of sediment from the upper reaches. This change resulted in downstream sediment concentration lower than sediment carrying capacity, leading to visible erosion in the midlower riverbed (Lai et al., 2017). Downstream of the TGD, the erosion depth in the midlower river channel is estimated to be $\sim 3.7 \mathrm{~m}$ on average in Yichang and less than $1 \mathrm{~m}$ in the middle reaches (Lai et al., 2017). Sediments having been retained for a long time in the midlower basin have reached an equilibrium with surrounding environment, thus producing the observed and calculated floodplain weathering signals (Figure 8b). After the TGD construction, the samples collected in the midlower reaches were dominated by these older and more weathered sediments, as observed in the downstream bank sediments sampled in 2014 and 2018 (Figure 4c). 

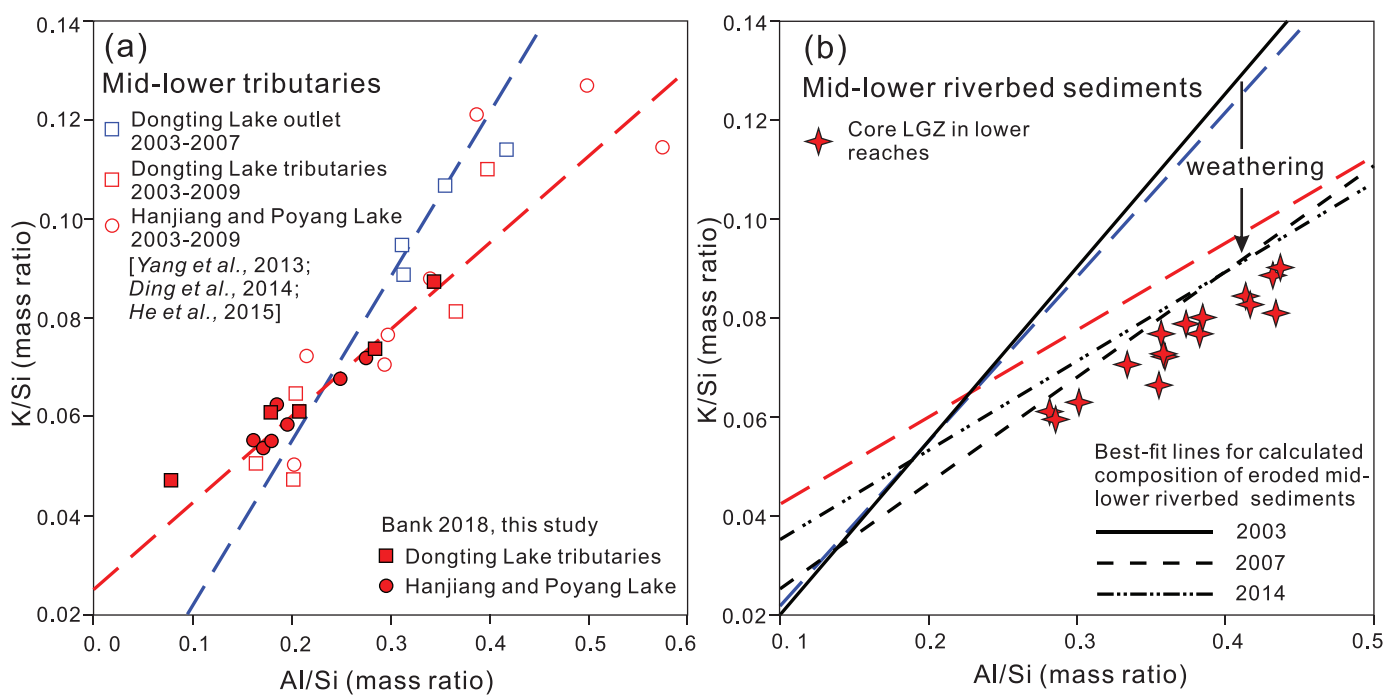

Figure 7. The variation of $\mathrm{K} / \mathrm{Si}$ versus $\mathrm{Al} / \mathrm{Si}$ of samples collected in the midlower reaches tributaries (a), of Core LGZ samples collected in lower mainstream and best-fit lines for simulated riverbed sediments (b). The blue and red dash lines are drawn based on Figure 3. The K/Si versus $\mathrm{Al} / \mathrm{Si}$ ratios of midlower riverbed sediments are simulated by Monte-Carlo method.

\subsection{Implication for Dissolved Fluxes From the Floodplain}

Generally, river flow conditions are dominated by the mixing of rapid surface runoff and deep groundwater (Calmels et al., 2011). In this study, the warm climate and long water-rock reaction time in the midlower Changjiang basin may be responsible for the sediment weathering in situ, resulting in enrichment of $\mathrm{K}$ in the interstitial waters (Figure 8). With time, these solutions reach a chemical equilibrium with the weathering products presented within the sediments (Ibarra et al., 2016; Winnick \& Maher, 2018). The downstream riverbed erosion since 2003 exposed highly weathered riverbed sediments and, thus, perhaps released significant amounts of interstitial water, which are rich in ions. This is confirmed by the increase of the dissolved K flux observed between 2003 and 2013 for the samples collected at Datong gauging station (Table 1). Indeed, the annual flux of dissolved $\mathrm{K}$ increased from $\sim 52.3 \times 10^{9} \mathrm{~mol} /$ year in 2003-2007 to $\sim 60.9 \times 10^{9} \mathrm{~mol} /$ year in 2010-2013 (Table 1), suggesting an increase of $8.6 \times 10^{9} \mathrm{~mol} / \mathrm{year}$.

It is possible to roughly estimate the $\mathrm{K}$ contribution from interstitial water to this increase. If we set the $\mathrm{Al} / \mathrm{Si}$ ratio of sediments from the upper Changjiang to $0.35 \pm 0.03$ (the SPM average), the corresponding $\mathrm{K} / \mathrm{Si}$ values for upstream-derived and midlower riverbed sediments can be estimated using the corresponding regression equations (Table S1). Thus, we calculate that the percentage of $\mathrm{K}$ leached from the upstreamderived sediment during their storage within the midlower reaches is $23.2 \% \pm 2.5 \%$, with the assumption of constant $\mathrm{Si}$ concentration as a function of time. If we set particulate $\mathrm{K}$ concentration to $0.64 \pm 0.06 \mathrm{~mol} / \mathrm{kg}$ (the SPM average of the upper reaches), the K loss per unit sediment during their storage within the midlower reaches is $0.15 \pm 0.02 \mathrm{~mol} / \mathrm{kg}$. The average midlower riverbed sediment flux in 2010-2013 increased by 11 Mt/year with respect to that in 2003-2007 (Changjiang Water Resources Commission, 2002-2016). As a consequence, the increased $\mathrm{K}$ flux released by interstitial water to the mainstream is $1.7 \pm 0.2 \times 10^{9} \mathrm{~mol} /$ year. In spite of the large uncertainty, such as the lack of correction for anthropogenic input, the release of interstitial water due to increased sediment flux from midlower riverbed accounts for $\sim 20 \%$ of the increase of the riverine dissolved K flux measured between 2003 and 2013. Yang et al. (2014) speculated that the total volume of upstream-derived sediments deposited in the midlower Changjiang valley in 1950-2000 is approximately $3.2 \mathrm{~km}^{3}$ (approximately $4,000 \mathrm{Mt}$ ). The potential $\mathrm{K}$ release flux from the interstitial water within the Changiang floodplain is thus estimated to be $6 \pm 0.8 \times 10^{11} \mathrm{~mol}, 1$ order of magnitude higher than annual flux of dissolved $\mathrm{K}$ released to the marginal sea. Our simple calculation implies that the TGD is responsible for $\sim 15 \%$ excess of dissolved K flux released to the East China Sea, in response to the erosion of downstream riverbed sediments and corresponding interstitial waters. 
(a) Before the TGD construction in 2003
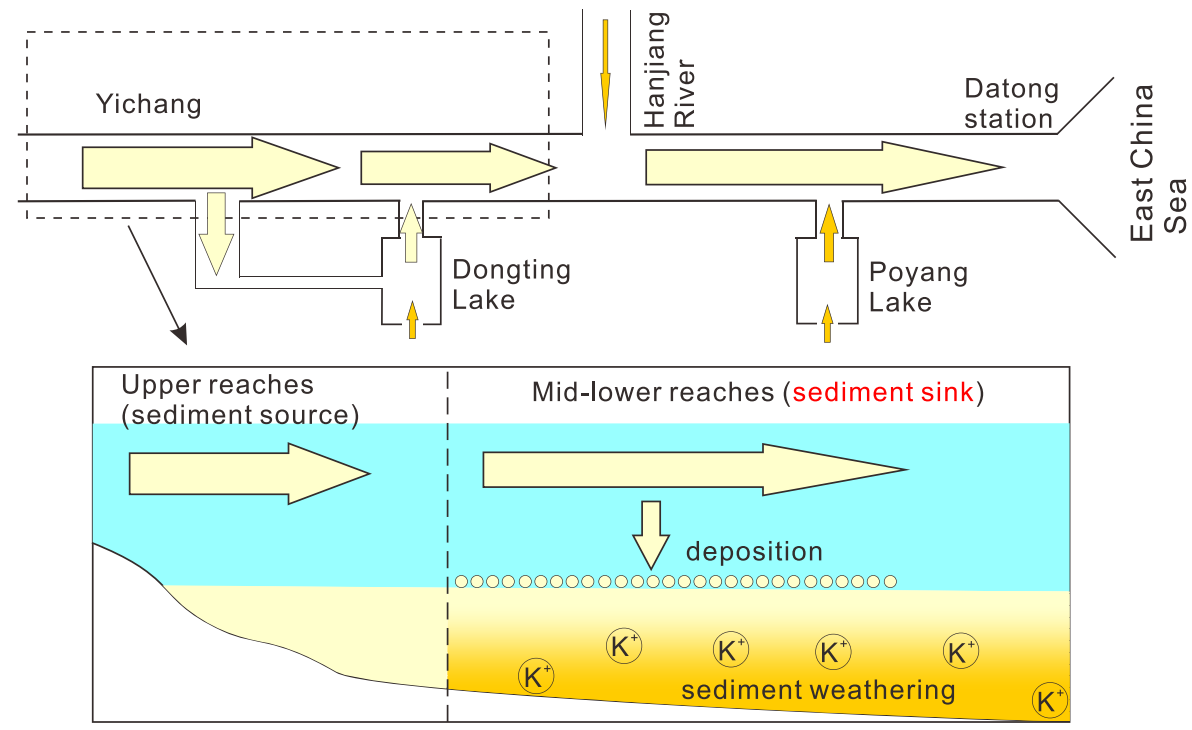

\section{(b) After the TGD construction}

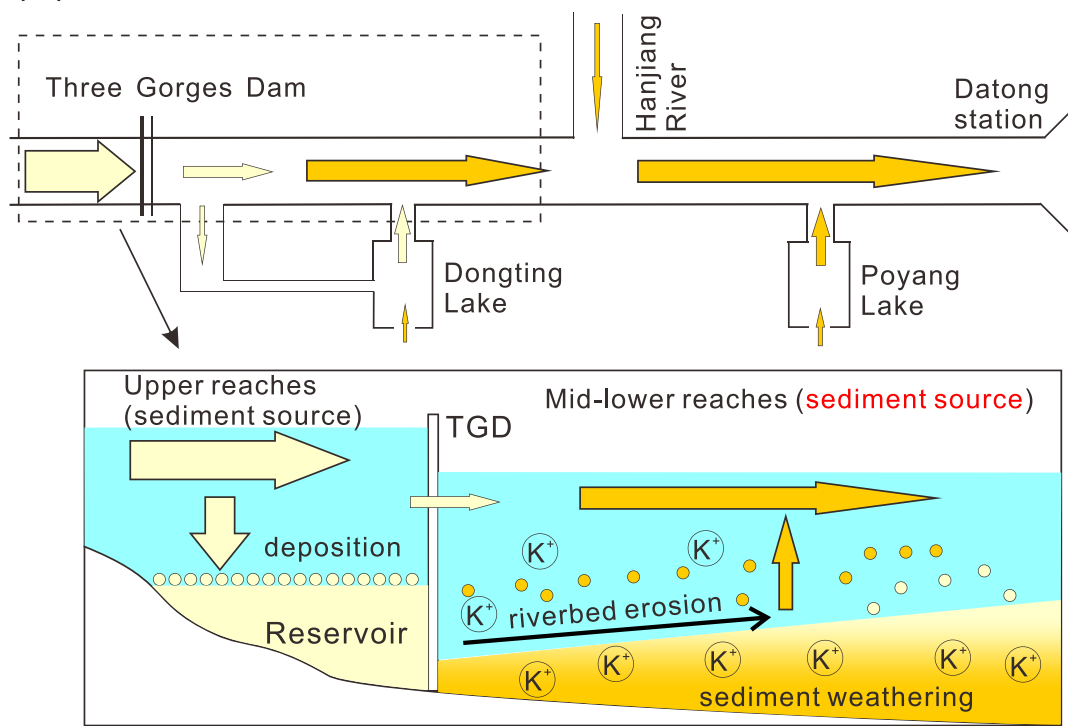

Figure 8. Schematic drawing showing sediment-transport pattern changes before (a) and after (b) the TGD operation and the possible mechanism for increased weathering signal after 2003. The width of arrow represents the amount of sediment flux, that is, the wider arrow means larger sediment flux. The dark yellow represents the sediments experiencing stronger weathering during storage in floodplain and riverbed. TGD $=$ Three Gorges Dam.

Human activities in large river systems and especially dam construction have significantly altered the sediment source-to-sink transport process and reduced sediment flux into the ocean, as is already evident in the Changjiang River (Chen et al., 2010; Yang et al., 2018). This work further reveals that not only the downstream sediment routing system is affected but also the sediment chemistry. Before the TGD operation, the weathering signals of samples collected along the mainstream overall reflect the general weathering characteristic of the sediments coming from the upper reaches, rather than floodplain weathering, because of the dominance of sediment contribution from the upper Changjiang. Most previous studies on chemical weathering in the Changjiang basin were based on samples collected before or during initial period of the TGD operation. A large bias is therefore possibly introduced while using these samples to constrain continental weathering and its controls at large scale. 
Table 1

The Total Dissolved K Flux Into the Sea of Changjiang (Yangtze) River

\begin{tabular}{|c|c|c|c|c|c|c|c|c|c|c|}
\hline & \multicolumn{2}{|c|}{2003} & \multicolumn{2}{|c|}{2005} & \multicolumn{2}{|c|}{2007} & \multicolumn{2}{|c|}{2010} & \multicolumn{2}{|c|}{2013} \\
\hline & Wet season & Dry season & Wet season & Dry season & Wet season & Dry season & Wet season & Dry season & Wet season & Dry season \\
\hline $\begin{array}{l}\mathrm{K}^{+} \text {Concentration } \\
(\mu \mathrm{M})\end{array}$ & $58.9^{\mathrm{a}}$ & $63.5^{\mathrm{d}}$ & $59.6^{\mathrm{a}}$ & $63.5^{\mathrm{d}}$ & $58.6^{\mathrm{a}}$ & $63.5^{\mathrm{d}}$ & $59.0^{\mathrm{b}}$ & $63.0^{\mathrm{b}}$ & $82.9^{c}$ & $63.5^{\mathrm{d}}$ \\
\hline $\begin{array}{l}\text { Water Discharge } \\
\left(\times 10^{9} \mathrm{~m}^{3}\right)^{\mathrm{e}}\end{array}$ & 647.0 & 277.8 & 627.3 & 274.2 & 549.6 & 221.2 & 730.1 & 292.0 & 531.3 & 256.5 \\
\hline $\begin{array}{l}\text { Dissolved K Flux } \\
\quad\left(\times 10^{9} \mathrm{~mol}\right)^{\mathrm{f}}\end{array}$ & \multicolumn{2}{|c|}{55.7} & \multicolumn{2}{|c|}{54.8} & \multicolumn{2}{|c|}{46.3} & \multicolumn{2}{|c|}{61.5} & \multicolumn{2}{|c|}{60.3} \\
\hline
\end{tabular}

${ }^{\mathrm{a}}$ Ding et al. (2014). ${ }^{\mathrm{b}}$ Wang et al. (2018). ${ }^{\mathrm{c}}$ Zhang et al. (2016). ${ }^{\mathrm{d}}$ The average of $\mathrm{K}^{+}$concentration of dry season in 2004 and 2006 , data come from Ding et al. (2014). ${ }^{\mathrm{e}}$ Data come from the CWRC website (http://www.cjw.com.cn/). ${ }^{\mathrm{f}}$ Dissolved $\mathrm{K}$ flux $=\mathrm{K}^{+}$concentration $\times$water discharge.

Dams retain almost all of the sediments derived from upper mountainous regions, which will limit the supply of fresh materials to the floodplain. For instance, at least $100 \mathrm{Mt} /$ year of upstream-derived sediments were trapped in the midlower lakes and valley due to overbank deposition before the TGD construction (Yang et al., 2006). As illustrated in Figure 4, the present-day midlower Changjiang basin is covered by cation-depleted older sediments, and there is a shortage of fresh materials or new sediments from the upper mountainous region. This change suggests the complex internal dynamic balance of sediment budget and chemistry in a large river system that is facing intense anthropogenic activities. Similar cases have been observed in almost all the large rivers worldwide, such as the Mississippi and Ebro Rivers (Batalla et al., 2004; Harmar et al., 2005). A total of 47,425 large dams ( $>15-\mathrm{m}$ height) have been constructed all over the world (Milliman \& Farnsworth, 2013). Although the dams indeed increased dissolved chemical flux by releasing interstitial water over short timescales, we argue that these dams artificially separate sediment connection between upper mountainous area and lower floodplain region and, thus, indirectly weaken the role of floodplain on regulating continental weathering and terrestrial material cycling over long timescales. Moreover, the human activities in large catchments, in particular dam constructions, exert a potential influence on the output flux of dissolved load. The anthropogenic perturbation on natural surface processes in large river systems deserves more in-depth integrated studies to verify these effects at a larger scale in the future.

\section{Conclusions}

This study investigated the impact of one of the largest dams in the world, the TGD, on the chemical composition of the downstream sediments, over a period of 10 years after its construction. The major conclusions can be summarized as follows:

1. The TGD construction affected sediment chemical composition and inferred weathering intensity. Before the TGD operation, overwhelming flux and rapid transfer of upstream-derived sediments deposited in the midlower reaches, masking the floodplain weathering signal. The sediments collected along the midlower mainstream at that time mostly reflect the weak weathering signals of the upper mountainous region. Since 2003, the upstream-derived sediments were largely retained upstream of the TGD, and a floodplain weathering signal was gradually disclosed in the midlower Changjiang basin. A possible consequence of this effect is an apparently stronger weathering degree of midlower mainstream sediments than expected, which is not representative of modern conditions. Caution should therefore be taken in studies of the downstream parts of large basins for determining control laws of continental weathering.

2. The release of interstitial water associated with erosion of deep layers of riverbed sediments in the midlower Changiiang mainstream likely resulted in the significant increase of dissolved $\mathrm{K}$ flux. Overall, the TGD not only affected the chemical composition of riverine sediments but has also introduced a small but not negligible bias to the chemical composition of the Changjiang dissolved load, resulting in potential artifacts in the quantification of continental weathering at large scale. Globally, the floodplains are well developed in large river systems and have a large potential ability for regulating silicate weathering and related $\mathrm{CO}_{2}$ consumption. Intensive damming activities artificially decrease the supply of fresh materials from mountainous regions, which indirectly weaken the role of floodplain in regulating 
continental weathering over long timescales. More work would therefore be necessary to quantify more precisely these effects in the Changiiang basin and in other large river basins in the future.

\section{Acknowledgments}

Data used in this study are available in Tables S2-S6 and in the EarthChem (http://dx.doi.org/10.1594/IEDA/ 111383 ) as well. This study was funded by the National Natural Science Foundation of China (Grant 41730531) and the National Program on Global Change and Air-Sea Interaction (GASIGEOGE-03). We thank Editor Amy East, Associate Editor Craig Rasmussen, Daniel Ibarra, and three anonymous reviewers for their constructive comments, which greatly improved the paper quality. C. Y. was supported by the China Scholarship Council for 2 year's PhD study in Laboratory of Oceanography of Villefranche-sur-Mer (LOV). Thanks to Xiangtong Huang, Ergang Lian, Xiaolong Liang, Yun Zhao, and Wang Zhan for their help in the field and lab work.

\section{References}

Batalla, R. J., Gomez, C. M., \& Kondolf, G. M. (2004). Reservoir-induced hydrological changes in the Ebro River basin (NE Spain). Journal of Hydrology, 290(1-2), 117-136.

Bi, L., Yang, S. Y., Li, C., Guo, Y. L., Wang, Q., Liu, J. T., \& Yin, P. (2015). Geochemistry of river-borne clays entering the East China Sea indicates two contrasting types of weathering and sediment transport processes. Geochemistry, Geophysics, Geosystems, 16, 3034-3052. https://doi.org/10.1002/2015GC005867

Bluth, G. J., \& Kump, L. R. (1994). Lithologic and climatologic controls of river chemistry. Geochimica et Cosmochimica Acta, 58(10), 2341-2359.

Calmels, D., Galy, A., Hovius, N., Bickle, M., West, A. J., Chen, M. C., \& Chapman, H. (2011). Contribution of deep groundwater to the weathering budget in a rapidly eroding mountain belt, Taiwan. Earth and Planetary Science Letters, 303, 8-58.

Changjiang Water Resources Commission (2002-2016). Changjiang Sediment Bulletin. Retrieved from http//www.cjh.com.cn (in Chinese)

Chen, J., Wang, F., Xia, X., \& Zhang, L. (2002). Major element chemistry of the Changjiang (Yangtze River). Chemical Geology, 187(3-4), 231-255.

Chen, Z., Wang, Z., Finlayson, B., Chen, J., \& Yin, D. (2010). Implications of flow control by the Three Gorges Dam on sediment and channel dynamics of the middle Yangtze (Changjiang) River, China. Geology, 38(11), 1043-1046.

Chetelat, B., Liu, C. Q., Wang, Q., \& Zhang, G. (2013). Assessing the influence of lithology on weathering indices of Changjiang river sediments. Chemical Geology, 359, 108-115.

Chetelat, B., Liu, C. Q., Zhao, Z. Q., Wang, Q. L., Li, S. L., Li, J., \& Wang, B. L. (2008). Geochemistry of the dissolved load of the Changjiang Basin rivers: Anthropogenic impacts and chemical weathering. Geochimica et Cosmochimica Acta, 72(17), $4254-4277$.

Ding, T., Gao, J., Tian, S., Shi, G., Chen, F., Wang, C., et al. (2014). Chemical and isotopic characteristics of the water and suspended particulate materials in the Yangtze river and their geological and environmental implications. Acta Geologica Sinica-English Edition, 88(1), 276-360.

Dynesius, M., \& Nilsson, C. (1994). Fragmentation and flow regulation of river systems in the northern third of the world. Science, 266(5186), 753-762.

Gaillardet, J., Dupré, B., \& Allègre, C. J. (1999). Geochemistry of large river suspended sediments: Silicate weathering or recycling tracer? Geochimica et Cosmochimica Acta, 63(23-24), 4037-4051.

Gaillardet, J., Dupré, B., Louvat, P., \& Allegre, C. J. (1999). Global silicate weathering and $\mathrm{CO}_{2}$ consumption rates deduced from the chemistry of large rivers. Chemical Geology, 159(1-4), 3-30.

Garrels, R. M., \& Mackenzie, F. T. (1971). Gregor's denudation of the continents. Nature, 231(5302), 382.

Gislason, S. R., Oelkers, E. H., Eiriksdottir, E. S., Kardjilov, M. I., Gisladottir, G., Sigfusson, B., et al. (2009). Direct evidence of the feedback between climate and weathering. Earth and Planetary Science Letters, 277(1-2), 213-222.

Grill, G., Lehner, B., Thieme, M., Geenen, B., Tickner, D., Antonelli, F., et al. (2019). Mapping the world's free-flowing rivers. Nature, 569 (7755), 215.

Guo, L., Su, N., Zhu, C., \& He, Q. (2018). How have the river discharges and sediment loads changed in the Changjiang River basin downstream of the Three Gorges Dam? Journal of Hydrology, 560, 259-274.

Guo, Y., Yang, S. Y., Su, N., Li, C., Yin, P., \& Wang, Z. (2018). Revisiting the effects of hydrodynamic sorting and sedimentary recycling on chemical weathering indices. Geochimica et Cosmochimica Acta, 227, 48-63.

Harmar, O. P., Clifford, N. J., Thorne, C. R., \& Biedenharn, D. S. (2005). Morphological changes of the Lower Mississippi River: Geomorphological response to engineering intervention. River Research and Applications, 21(10), 1107-1131.

He, M., Zheng, H., Clift, P. D., Tada, R., Wu, W., \& Luo, C. (2015). Geochemistry of fine-grained sediments in the Yangtze River and the implications for provenance and chemical weathering in East Asia. Progress in Earth and Planetary Science, 2(1), 32.

He, M., Zheng, H., Huang, X., Jia, J., \& Li, L. (2013). Yangtze River sediments from source to sink traced with clay mineralogy. Journal of Asian Earth Sciences, 69, 60-69.

Ibarra, D. E., Caves, J. K., Moon, S., Thomas, D. L., Hartmann, J., Chamberlain, C. P., \& Maher, K. (2016). Differential weathering of basaltic and granitic catchments from concentration-discharge relationships. Geochimica et Cosmochimica Acta, 190, $265-293$.

Kump, L. R., Brantley, S. L., \& Arthur, M. A. (2000). Chemical weathering, atmospheric $\mathrm{CO}_{2}$, and climate. Annual Review of Earth and Planetary Sciences, 28(1), 611-667.

Lai, X., Yin, D., Finlayson, B. L., Wei, T., Li, M., Yuan, W., et al. (2017). Will river erosion below the Three Gorges Dam stop in the middle Yangtze? Journal of Hydrology, 554, 24-31.

Louvat, P., \& Allègre, C. J. (1997). Present denudation rates on the island of Reunion determined by river geochemistry: basalt weathering and mass budget between chemical and mechanical erosions. Geochimica et Cosmochimica Acta, 61(17), 3645-3669.

Luo, X. X., Yang, S. L., \& Zhang, J. (2012). The impact of the Three Gorges Dam on the downstream distribution and texture of sediments along the middle and lower Yangtze River (Changjiang) and its estuary, and subsequent sediment dispersal in the East China Sea. Geomorphology, 179, 126-140.

Lupker, M., France-Lanord, C., Galy, V., Lavé, J., Gaillardet, J., Gajurel, A. P., et al. (2012). Predominant floodplain over mountain weathering of Himalayan sediments (Ganga basin). Geochimica et Cosmochimica Acta, 84, 410-432.

Maharana, C., Srivastava, D., \& Tripathi, J. K. (2018). Geochemistry of sediments of the Peninsular rivers of the Ganga basin and its implication to weathering, sedimentary processes and provenance. Chemical Geology, 483, 1-20.

Maher, K., \& Chamberlain, C. P. (2014). Hydrologic regulation of chemical weathering and the geologic carbon cycle. Science, 343(6178), 1502-1504.

Milliman, J. D., \& Farnsworth, K. L. (2013). River discharge to the coastal ocean: A global synthesis. Cambridge University Press.

Moon, S., Chamberlain, C. P., \& Hilley, G. E. (2014). New estimates of silicate weathering rates and their uncertainties in global rivers Geochimica et Cosmochimica Acta, 134, 257-274.

Rudnick, R. L., \& Gao, S. (2003). Composition of the continental crust. Treatise Geochemistry, 3, 659.

Syvitski, J. P., Vörösmarty, C. J., Kettner, A. J., \& Green, P. (2005). Impact of humans on the flux of terrestrial sediment to the global coastal ocean. Science, 308(5720), 376-380.

Torres, M. A., West, A. J., \& Clark, K. E. (2015). Geomorphic regime modulates hydrologic control of chemical weathering in the AndesAmazon. Geochimica et Cosmochimica Acta, 166, 105-128. 
Wang, X., Yang, S. Y., Ran, X., Liu, X. M., Bataille, C. P., \& Su, N. (2018). Response of the Changiiang (Yangtze River) water chemistry to the impoundment of Three Gorges Dam during 2010-2011. Chemical Geology, 487, 1-11.

West, A. J., Galy, A., \& Bickle, M. (2005). Tectonic and climatic controls on silicate weathering. Earth and Planetary Science Letters, 235(1-2), 211-228.

Winnick, M. J., \& Maher, K. (2018). Relationships between $\mathrm{CO}_{2}$, thermodynamic limits on silicate weathering, and the strength of the silicate weathering feedback. Earth and Planetary Science Letters, 485, 111-120.

Xu, K., \& Milliman, J. D. (2009). Seasonal variations of sediment discharge from the Yangtze River before and after impoundment of the Three Gorges Dam. Geomorphology, 104(3-4), 276-283.

Yang, H., Yang, S. L., Xu, K. H., Milliman, J. D., Wang, H., Yang, Z., et al. (2018). Human impacts on sediment in the Yangtze River: A review and new perspectives. Global and Planetary Change, 162, 8-17.

Yang, S. L., Milliman, J. D., Xu, K. H., Deng, B., Zhang, X. Y., \& Luo, X. X. (2014). Downstream sedimentary and geomorphic impacts of the Three Gorges Dam on the Yangtze River. Earth Science Reviews, 138, 469-486.

Yang, S. Y., Jung, H. S., \& Li, C. (2004). Two unique weathering regimes in the Changjiang and Huanghe drainage basins: Geochemical evidence from river sediments. Sedimentary Geology, 164(1-2), 19-34

Yang, S. Y., Li, C., Wang, Z., Wang, X., \& Shu, J. (2013). Heterogeneity of geochemical compositions of the Changjiang river sediments and provenance indication. Quaternary Science Reviews, 33(4), 645-655.

Yang, Z., Wang, H. J., Saito, Y., Milliman, J. D., Xu, K., Qiao, S., \& Shi, G. (2006). Dam impacts on the Changjiang (Yangtze) River sediment discharge to the sea: The past 55 years and after the Three Gorges Dam. Water Resources Research, 42, W04407. https://doi.org/10.1029/ 2005WR003970

Zhan, W., Yang, S., Liu, X., Li, J., \& Choi, M. (2010). Reconstruction of flood events over the last 150 years in the lower reaches of the Changiiang River. Chinese Science Bulletin, 55(21), 2268-2274.

Zhang, Y., Gan, Y., Li, X., Liu, Y., Yu, K., \& Zhang, B. (2016). Water chemical characteristics and controlling factors of the Yangtze river in the wet season. Resources and Environment in the Yangtze, 25(4), 645-654. (in Chinese with English abstract)

Zhao, Y., Zou, X., Gao, J., Wang, C., Li, Y., Yao, Y., et al. (2018). Clay mineralogy and source-to-sink transport processes of Changjiang River sediments in the estuarine and inner shelf areas of the East China Sea. Journal of Asian Earth Sciences, 152, 91-102. 